\title{
From Performance Appraisal to Performance Management
}

\author{
${ }^{1}$ Ms. Leena Toppo, ${ }^{2}$ Dr. (Mrs.) Twinkle Prusty \\ ${ }^{1,2}$ (Faculty of Commerce, Banaras Hindu University, INDIA)
}

\begin{abstract}
Performance appraisal and performance management were one of the emerging issues since last decade. Many organizations have shifted from employee's performance appraisal system to employee's performance management system. This paper has focused to study the evolution of employee's performance appraisal system, critics the system suffered and how the performance management system came to the practice. The main purpose of this paper is to differentiate these two systems, employee's performance appraisal and management system. This paper uses a review of the literature to evaluate the development of appraisal system and argues the critic areas of appraisal system. The review identified as advancement in the management field and growing complexity in corporate sectors demand more capable HR, so mare appraisal of employee's performance is not sufficient. Employee's contribution should be aligned with organizational objectives and strategy. Performance management eliminates the shortcomings of performance appraisal system to the some extent.
\end{abstract}

Keywords: Human resource (HR), HR development, performance appraisal, performance management, performance evaluation.

\section{INTRODUCTION}

Organizations are run and steered by people. It is through people that goals are set and objectives are realized. The performance of an organization is thus dependent upon the sum total of performance of its members. The success of an organization will therefore depend on its ability to measure accurately the performance of its members and use it objectively to optimize them as a vital resource (Biswajeet 2009). In the present highly competitive environment, organizations have to ensure peak performance of their employees continuously in order to compete and survive at the market place effectively (Prasad 2005). Performance of an individual can be defined as the record of outcomes produced as specified job functions or activities during a specified time period (Bernardin 2007). The term performance refers to a set of outcome produced during a certain period of their job time and does not refer to the traits, personal characteristics, or competencies of the performer. The evaluation of employee's performance reveals the contribution of an individual in the organization's objectives. People do not learn unless they are given feedback on the results of their actions. For corrective actions to take place feedback must be provided regularly and it should register both successes and failures (Biswajeet 2009).

Appraisal is the evaluation of worth, quality or merit, so performance appraisal of employees means the evaluation of their performance performed during a certain period of time. In the organizational context, performance appraisal is a systematic evaluation of personnel by supervisors or others familiar with their performance (L.M. Prasad). Performance appraisal is also described as merit rating in which an individual is rated as better or worse in comparison to others. This is one of the oldest and most universal practices of management (Tripathi 2005). This is a process which reveals that how well employees perform their jobs when the performance compared with the predetermine set of standards (L Mathis \& John H. Jackson). Merit rating is used basically for promotion of employees. However performance appraisal is more comprehensive term for such activities, because its use extends beyond ascertaining eligibility for promotion. Such activities may be training and development, salary increase, transfer, discharge, etc. besides promotion (Prasad, 2005). According to Beach (1980),

"Performance appraisal is a systematic evaluation of the individual with regard to his or her performance on the job and his potential for development."

Worldwide, performance appraisals are used in nearly all organizations. There are different tools and number of goals that performance appraisals focus to examine individual's performance and potential of development. So at its core, the performance appraisal process allows an organization to measure and evaluate individually the employee's behaviour and accomplishments over a specific period of time (De Vries et al. 1981). By using a formal system performance appraisals have many advantages if they are designed and implemented properly. Not only in reward allocation, promotion/demotions, layoffs/recalls, transfers and selecting training and development program for employees but it may also assist individual employee's decisions regarding career choices and the subsequent direction of individual time and effort. Additionally, performance appraisals may increase employee's commitment and satisfaction (Wiese and Buckley, 1998).

At a glance the main objectives of performance appraisal point out the following: 
1. Provide inputs to (a) system of rewards comprising salary increment, appreciations, additional responsibilities, promotions, etc., and (b) salary administration.

2. Generate adequate feedback and guidance from the reporting officers to the employee.

3. Enhancing employee's effectiveness: helps the employee to overcome his weaknesses and improve his performance by providing appropriate training and development program.

4. Help identifying employee for the purpose of motivating, training and developing them.

5. Generate significant, relevant, free and valid information about employees.

\section{Early History}

Somewhere or other, everyone had the experience of performance appraisal in some context. This can be traced back for thousands of years. As we go through the history of performance appraisal in an informal sense, performance appraisal is as old as mankind itself. Although not called performance appraisal, the Bible has many examples where the evaluation of individual performance is an important issue. "The Lord has filled him (Bezalel) with the spirit of God, in wisdom and understanding, in knowledge and all manner of workmanship to design artistic works, to work in gold and silver and bronze, in carving wood, and to work in all manner of artistic workmanship" (Exodus, 35, pp. 31-3). In this instance, Moses selected men who were known to be most skilled craftsmen from the tribes of Israel to build and furnish the tabernacle of the Lord in about 1350 BC (Wiese and Buckley 1998). Thus, proving that individual performance and appraisal of performance are important to bring out the effectiveness of the work performed as a goal. In a formal sense, performance appraisal of an individual began in the Wei dynasty (A. D. 261-265) in China, where an Imperial Rater appraisal the performance of members of the official family (Monappa and Mirza, 1997). Further, that in 1648 it was reported that the Dublin (Ireland) Evening Post evaluated legislators by using a rating scale based upon personal qualities (Hackett, 1928). In 1800s the New York City Civil Service in USA introduced a formal appraisal program shortly before First World War. However, formal appraisal of employee's performance is believed to have been started for the first time during the First World War, when at the instance of Walter Dill Scatt, the US Army: adopted the "Man-to-man" rating system for evaluating military personnel (Oberg, 1972). This early employee's appraisal system was called 'merit rating'. From the army this concept entered the business field and was restricted to hourly-paid workers. During 1920s, relational wage structures for hourly-paid workers were adopted in industrial units and each worker was used to be rated in comparison to others for determining wage rates. In the 1940s behavioural methods were developed using a motivational approach. These included behavioural anchored rating scales (BARS), behavioural observation scales (BOS), behavioural evaluation scales (BES), critical incident, and job simulation. All these judgments were used to determine the specific levels of performance criteria to specific issues such as customer service and rated in factors such as "excellent", "average", "need to improve" or "poor". Post-1945 developed into the results-oriented approaches and led to the development of management by objectives (MBO) (Prowse \& Prowse, 2009).

In the 1960s the development of self-appraisal by discussion led to specific time and opportunity for the appraisee to evaluate their performance reflectively in the discussion and the interview developed into a conversation on a range of topics that the appraise needed to discuss in the interview. In the 1990s 360-degree appraisal developed, where information was sought from a wider range of sources and the feedback was no longer dependent on the manager-subordinate power relationship but included groups appraising the performance of line managers and peer feedback from peer groups on individual performance (Redman and Snape, 1992).

So Since 1940s, the philosophy of performance appraisal has undergone tremendous changes (Beach, 1975). The common terms used include merit rating, behavioural assessment, employee evaluation, personnel review, staff assessment, progress report and performance appraisal. However the most widely used term is performance appraisal (Prasad, 2005).

\section{Criticism of Performance Appraisal}

In the present era almost all the organization have some kind of employees appraisal system, though the systems are not free from critics. First dominant critique is the management framework using appraisal as an "orthodox" technique that seeks remedies the weakness and proposal of appraisals as a system to develop performance (Beach 2005). The orthodox approach argues about the purpose of performance appraisal system. In the system appraisal helps the employees to overcome his weakness and help identifying employees for the purpose of motivating, training and development (Rao and Pareek 2006). This conflicts with evaluation of past performance and distribution of rewards based on past performance. As to evaluate appraisers' performance the appraiser challenges to play opposite roles as both monitors and judges of performance and as an understanding counsellor (Randell 1994). Here, the managers are reluctant to make negative judgments on individual's performance as it could be de-motivating leading to appraise accusations of lack of managerial support and contribution to an individual's poor performance (McGregor,1957). 
To avoid this conflict appraiser can rate an employee with the technique "central tendency" in which managers rate all criterions in the middle rating point. But this rating system is influenced by the organizational politics. Politics involved deliberate attempts by individuals to enhance or self-interests when conflicting courses of action are possible, and ratings and decision were affected by potential sources of bias or inaccuracy in their appraisal ratings (Longeneker and Ludwig, 1990). Political judgment influenced further more by overrating some clear competencies in performance rather than being critical across the range of measures, known as the "halo effect", and some competencies are lower they may prejudice the judgement across the positive review, known as the "horns effect" (Advisory, Conciliation and Arbitration Service, 1996).

Some ratings may only include recent events, and these are known as "recency effects". In this case only recent events are noted compared to managers gathering and using evidence throughout the appraisal period (Prowse and Prowse 2009). Another very common critic is the performance rating suffer from many biases like age, ethnicity, gender, physical appearance, attitudes and values, in-group/out-group, personal like/dislike and so on (Cook Mark, 1995).

In spite of many criticisms performance appraisal counted as a very important instrument to evaluate the performance of employees. Most organization have some type of employees appraisal or review system and most are ill equipped to appreciate the short comings of these systems (Potgieter Lyle 2002).

\section{Performance appraisal and Performance management}

In the late $20^{\text {th }}$ century, a great change in approaches to performance appraisal systems across the world was seen. There has been a great realization that it is more important to focus on defining, planning and managing performance than merely appraising performance (Pareek and Rao, 2006). Performance appraisal is the traditional approach to evaluating the performance of an employee. As many people think that performance management (some call it performance development) is a new name given to well-established term performance appraisal and there is no difference between the two (Prasad 2005) most of the organizations take performance management synonymously of performance appraisal. Yet performance management is clearly more than a new name for performance appraisal (Edmonstone, 1996). The increased competitive nature of the economy and rapid changes in the external environment has forced many organizations to shift from reactive performance appraisals to the proactive performance management to boost productivity and improve organizational performance (Nayab, May, 2011). Most organizations prefer to call their systems as performance management system rather than performance appraisal systems. This is most welcome change of the last fifteen years (Pareek and Rao, 2006).

Day to day corporate environment is becoming more competitive and comprehensive. For survival and competition the market environment organizations need well competent employees who can face present and uncertain future challenges. So organizations always try to seek the new ways to improve employee's performance. Traditionally, this objective was attempted to achieve through employees performance appraisal which was more concerned with telling employees where they lacked in their performance. Though performance appraisal served the purpose to some extent, but not considered enough to raise the employee performance at the most desirable level (Prasad 2005).

Snell and Bohlander defines (2007) performance appraisal as a process, typically performed/delivered by a supervisor to a subordinate, designed to help employees understand their roles, objectives, expectations and performance success. Further he explains performance management is the process of creating a work environment in which people can perform to the best of their abilities. It is a whole work system that begins when a job is defined. So performance appraisal is a way, by which senior officers keeps some periodic objective (for specific period) to his subordinates, clears the expected role and explain his performance success by his actual performance with pre-determined standard, and performance management is the way to creating the whole working environment so the people can perform their best.

Dessler (2008) defines performance appraisal means evaluating an employee's current and /or past performance relative to his/her performance standards. He explains performance appraisal always assumes that the employees understood what his/her performance standards were, and that the supervisor also provides the employees with the feedback, development, and incentives required to help the person eliminate performance deficiencies or to continue to perform above par. This aims at improving employee's performance.

Further he explains performance management as an integrated process, may defined as a process that consolidates goal setting, performance appraisal, and development into a single, common system, the aim of which is to ensure that the employee's performance is supporting the company's strategic aims. Prasad (2005) defines performance management is the process of planning performance, appraising performance, giving its feedback, and counselling an employee to improve his performance. So performance appraisal is considered as the key ingredient or an important step of whole performance management system (Prasad 2005, Dessler 2008). Potgieter (2002) conclude performance appraisal systems were the precursor to today's performance management. 
Performance management is a systematic process for improving organizational performance by developing the performance of individuals and teams (Armstrong 2006). The overall aim of performance management is to establish a high performance culture in which individuals and team take responsibility for the continuous improvement of business processes and for their own skills and contributions within a framework provided by effective leadership. So the objectives of both performance appraisal and performance management, to develop the capacity of employees so that the performance of every individual can be improve is same, so both systems can be counted as a human resources developing instrument, with differences in scope. While the interest in measuring performance and linking with rewards remains the same (Pareek and Rao 2006).

\section{Performance management overtaking Performance appraisal}

Maximizing performance is a priority for most organizations today, and performance management is a part of a link between organizational strategy and results (Bhatia, 2006). As Potgieter (2005) conclude that performance appraisal systems were the precursor to today's performance management. He explains performance appraisal systems typically based on a review of how a person completed their job for the year, conducted annually or twice less frequently, for review of salary payment, bonus, or for promotion, typically paper based where HR is the custodian of the information, or they are conducted less formally and without any documentation.

Further he explains performance management as a definition which is specific objectives for an employee for the next performance period (normally the next quarter or half a year), backed up by a job description which takes into account the normal expectation for that position. If objectives are met a review made for personal development objective, remuneration/bonus etc. performance management system is usually fully automated where the information is accessible to all any time, has features such a Performance Diary. Here the explanations reveal performance management system trying to meet the short comings of performance appraisal system.

The increasing use of performance management by employers reflects several things. Dessler (2008) describe three important points that compel employers to use performance management system than performance appraisal system.

1. Growing importance of the total quality management (TQM), the term performance management gained its popularity in early 1980's when total quality management programs received utmost importance for achievement of supervisor standards and quality performance. Tools such as job design, leadership development, training and reward system received an equal impetus along with the traditional performance appraisal process in the new comprehensive and a much wider framework. Performance management is an ongoing communication process which is carried between the supervisors and the employees throughout the year.

2. Performance management as a process explicitly recognizes that in today's globally competitive industrial environment, every employee's efforts must focus like a laser on helping the company to achieve its strategic goals. In that regard, adopting an integrated, performance management approach to guiding development, and appraising employees also aids the employer's continues important efforts.

3. Various studies reflect the fact that traditional performance appraisal are often not just useless but counterproductive (Lee and Son, 1998; Antonioni, 1994).

One of the important reasons of most of the organizations shifting from performance appraisal to performance management is the short coming of performance appraisal system, even though the main objectives of performance appraisal and performance management is to improve the performance of employees. The main objective of a performance appraisal is to improve the employee performance by identifying the strengths and weakness of an employee to guide for formulation of suitable training and development program (Tripati 2005). The other hand the main objective of performance management system is to achieve the capacity of the employees to the full potential in favour of both the employee and the organization, by defining the expectations in terms of roles, responsibilities and accountabilities, required competencies and the expected behaviours.

In comparison of performance appraisal and performance management, performance appraisal sets job standards and evaluates past performance based on such set standards, it mainly used as a tool for employee evaluation in which the managers were impelled to make subjective judgment about the performance and behaviour of the employees against the predetermined job standards. Whereas performance management aims at managing performance real-time to ensure performance reaches the desired levels. It is a continuous and on-going proactive mechanism to manage the performance of an employee achieves the set targets on a real-time basis, without reviews or corrective actions at some point in the future. It is line activity and remains ingrained in the employee's day to day work. 


\section{Focus}

Performance appraisal were mostly narrowly focused for measuring the degree of accomplishment of on individual where supervisors had a major role to play in judging the past performance of an employee without soliciting active involvement of the employee. Performance management focused on front end planning instead of looking backward, the focus is on ongoing dialogue instead of ratings.

\section{Alignment}

Very often, the annual appraisal is performance on the employee anniversary which does not coincide with any particular performance period. This makes it near impossible to align the employee objectives with the organizations strategic goals as they are released or modified. If appraisals are conducted annually on the anniversary date, it is only possible to align at best only $50 \%$ of staff with future objectives.

As expectations are modified when a performance management system is introduced, most organizations switch to defined performance periods this means that the performance reviews are conducted quarterly or half yearly and enable management to direct effort to those objectives that need to be performance according to the strategic or operating plan.

\section{Approach}

Performance Appraisal considered as a retrospective journey in the individual's previous working year, where managers, where managers, very often perfunctorily, "judge" the performance of staff, the supervisor acts as a judge. Whereas performance management aims of the relationship based on it being to coach and to contribute to the development and growth of individual, a supervisor assumes the role of a coach or mentor. PM is inspired to the concept of "management by agreement or contract", PA is instead based on the concert of "management by command" (Armstrong, 2006).

\section{Conclusion}

In any organization each individual's performance keeps its own importance in the success of organization. With the changing competitive business environment the effective and efficient use of resources is very important for the survival of organization in market. And evaluation of the performance of all the resources involved in organizational operation is also very essential in order to achieve organizational goal. As human resource is considered the most valuable and complicated resource in an organization, appraisal of the HR is also complicated and very essential. Employee performance appraisal practice is not the new concept. In a work group, members, consciously or unconsciously, make opinion about others. The opinion may be about their quality, behaviours, way of working etc. such an opinion becomes the basis for interpersonal interaction. In the same way, when supervisors give opinion about their subordinate it becomes basis for evaluation of their performance (Prasad 2007). With the increasing comprehensiveness in business field performance appraisal has became more formal and structured. Although performance appraisal evaluate the past performance of employees and helps in eliminating the shortcoming this system only is not sufficient to bring out the results what today's competitive world demands, because this system emphasis on evaluation of individuals or team task. As Mondy and Noe (2007) define "Performance Appraisal is a formal system of review and evaluation of individual or team task performance." The focus of performance appraisal system in most firms remains on the individual employees. Regardless of the emphasis, an effective employee's appraisal system evaluates accomplishments and initiates plans for development, goals and objectives.

Performance management consists of all organizational process that determine how well employees, teams and ultimately, the organization perform. The process includes HR planning, employee recruitment and selection, T\&D, career planning and development and compensation. Performance appraisal is especially critical to its success. An organization must have some means of assessing the level of individual and team performance in order to make appropriate development plans. While performance appraisal is but one component of performance management it is vital in that it directly reflects the organization's strategic plan (Mondy and Noe, 2007). So as many people considered that the PM and PA are different name of same system is not true but performance appraisal is the precursor for performance management system. Performance management has wider scope than performance appraisal that came out to fulfil the short coming PA (Prasad, 2007). Performance management is integrated process of performance planning, performance appraisal, performance feedback performance counselling (Prasad 2005) or consolidates goal setting, performance appraisal, development in to a single, common system, the aim of which is to ensure that employee's performance is supporting the company's strategic aim (Desselor 2008). 


\section{References}

[1] B. Pattanayak, Human Resource Management (PHI Learning Private Limited, 2009).

[2] L.M. Prasad, Human Resource Management (Sultan Chand \& Sons: Educational Publishers, 2006).

[3] H John Bernardin, Human Resource Management (Tata McGraw-Hill Publishing Company Limited, 2007).

[4] P.C. Tripathi, Human Resource Development (Sultan Chand \& Sons: Educational Publishers, 2006).

[5] Robert L. Mathis and John H. Jackson, Human Resource Management (THOMSON South-Western, 2004)

[6] S. Dale Beach, Personnel: The management of people at work (Macmillan Publishing Company, 1980).

[7] D. L. DeVries, Morrison, A.M. Shullman, and M. L. Gerlach, Performance Appraisal on the line, Center for Creative Leadership (Greensboro, NC, 1981)

[8] Danielle S. Wiese and M. Ronald Buckley, The evaluation of the performance Appraisal process, Journal of management History, 4 (3), 1998, 233-249.

[9] Arun Monappa and Mirza S. Saiyadain, Personnel Management (Tata MacGram-Hill Publishing House Company Limited, 1997).

[10] J. D. Hackett, Rating Legislator, Personnel, 7(2), 1928, 130-31.

[11] Oberg Wonston, Making Performance Relevant, Harward Business Review, 50(1), 1972, 61.

[12] Peter Prowse and Julie Prowse, The Dilemma of Performance Appraisal, Measuring Business Excellence, 13(4), 2009, 69-77.

[13] T. Redman and E. Snape, Upward and onward: Can Staff Appraise their management, Personnel Review, 21(7), 1992, 32-46.

[14] S. Dale Beach, Personnel: The management of people at work (Macmillan Publishing Company, 1980).

[15] S. Dale Beach, New Directions in Performance Management, in Beach (Ed.), Managing Human Resources: Personnel Management in Transition (Blackwell, Oxford, 2005)

[16] U. Pareek and T.V. Rao, Designing and Managing Human Resource System, (Oxford and IBH Publishing Co. Pvt. Ltd. 2006).

[17] G. Randell Performance Appraisal, in K. Sisson (Ed.), Personnel Management: Comprehensive Guide to Theory and Practice in Britain (Blackwell, Oxford, 1994).

[18] D. Mc Gregor, An uneasy look at performance appraisal, Harvard Business Review, 35 (3), 1957, 89-95.

[19] C. O Longenecker and D. Ludwig, Ethical dilemmas in Performance appraisal revised, Journal of Business Ethics, 9, 1990, 961969.

[20] Advisory, Conciliation and Arbitration Service, Employee Appraisal Advisory, Conciliation and Arbitration Service, Landon, 1996.

[21] Mark Cook, Performance appraisal and true performance, Journal of managerial Psychology, 10 (7), $1995,3-7$.

[22] Lyle Potgieter, Performance Management, Dec 15, 2002. www.pmia.org.au/white/appvperf.pdf

[23] John Edmonstone, Appraising the state of performance appraisal, Health Manpower Management, 22(6), $1996,9-13$.

[24] N. Nayab and Linda Richter, The difference Between Performance Appraisal and performance Management, May 18, 2011, www.brighthub.com/office/human-resources/article/84772

[25] Scort Snell and George Bohlander, Human Resource Management (Thomson South-Western, 2007).

[26] Gary Deessler, Human Resource Management (Pearson Education, 2008).

[27] Michael Armstrong, Human Resource Management Practice (Kogan Page Ltd. Landon and Philadelphia, 2006).

[28] S.K. Bhatia, Human Resource Management: A Competitive Advantage (Deep \& Deep Publication Pvt. Ltd, 2006).

[29] Mushin Lee and Byoungho Son, The Effects of Appraisal Review Content on Employees' Reaction and Performance, International Journal of Human Resource Management, 1, February 1998, 283.

[30] David Antonioni, Improve the Management Process before Discontinuing Performance appraisal, compensation and Benefits Review, May-June 1994, 29.

[31] R. Wayne Mondy and Robert M. Noe, Human Resource Management (Pearson Education, 2007). 